\title{
The Concept of Mangrove ECO Tourism Master Plan in Belitung District Indonesia
}

\author{
Rustam Hakim Manan ${ }^{1}$ \\ ${ }^{1}$ Department of Landscape Architecture \\ Faculty of Landscape Architecture and Environment Technology- Universitas Trisakti \\ Jakarta, Indonesia
}

\begin{abstract}
Nature and forest-based tourism areas must pay attention to environmental, aesthetic principles that are harmonious and balanced. This area requires a design concept so that the development of the area can be made as beautiful as possible and carried out by utilizing measurable and efficient costs. The location of the activity chosen is the protected forest area of Sungai Berang, Selat Nasik Island in Belitung District, which has a specific characteristic but is still in the level of homogeneity of the small island communities, namely the mangrove area. The methodology used is a general approach through the Basic Strategy Approach, Operational Strategy Approach, Special Approach. The final result obtained is the basic concept of mangrove tourism forest design which includes the spatial concept, accessibility concept, recreational infrastructure concept and management concept.
\end{abstract}

Keywords: Tourist area; Basic Strategy Approach; Operational Strategy Approach; Specific Approach

\section{INTRODUCTION}

Management of mangrove-based tourism areas is a new trend and positive opportunities that are of double benefit. With mangrove planting arrangements and the provision of adequate tourist facilities, a mangrove area can be printed into an attractive forest tourism area and can also improve the regional economy. The use of mangroves for ecotourism is also in line with the shift in tourist interest from old tourism to new tourism that manages and seeks specific, natural, and biodiversity-specific ecotourism destinations. ${ }^{1}$ Ecotourism is an environmentally responsible tourism activity that is generally carried out in unspoiled areas. In addition to enjoying the beauty of nature, ecotourism also involves elements of education, understanding and support for nature conservation efforts and improving the economy of the local community ${ }^{2}$. Mangrove tourism is closely related to the environmental ecosystem of a region. Mangrove ecosystems have components of natural resources in the form of landscapes, flora, fauna and local communities interacting with each other to become an ecosystem unit that has important ecological, economic and social functions in development in coastal areas. Mangrove forest ecosystems are complex and dynamic, but unstable. The complexity of this ecosystem shows that mangrove forests contribute a large contribution to organic detritus that supports the food web in the ecosystem. The wealth of mangrove natural resources in the form of unique vegetation formations, animals and associations that exist in the mangrove ecosystem has the potential that can be sold as a tourist attraction, especially ecotourism that offers the concept of education and conservation. Ecotourism has become one of the choices in promoting a unique and authenticated environment while at the same time becoming a tourist visiting area. The initial step in the development of mangrove forest ecotourism requires a landscape-based ecotourism planning by optimizing the biophysical potential of the mangrove forest ecosystem, namely the determination of ideas or concepts or concepts in a simple but clear design. Landscape planning specializes in systematic study of land areas for various needs in the future through observing ecological problems and interdisciplinary cooperation is an absolute requirement to get to the policy product or land use. $^{3}$

Mangrove ecosystems are environments that have special characteristics because the forest floor is regularly inundated by water which is affected by salinity and fluctuations in water level due to tides ${ }^{4}$. Mangrove forests are also known as tidal forestcoastal woodland, vloedbos and brackish forests ${ }^{5}$. Located on the border between land and sea, precisely in coastal areas and around river mouths that are affected by tides ${ }^{6}$. Mangrove forest is a type of forest that grows in tidal areas (especially in protected beaches, lagoons, river mouths) that are inundated during high tides and free from inundation at low tide, the plant community salt tolerant. The mangrove ecosystem is a system consisting of organisms that interact with environmental factors in a mangrove habitat.

The characteristics of mangrove forests, apart from their unique habitat, are: having relatively few tree species; has unique roots such as anchor curved and towering on the mangrove Rhizophora spp, and roots that stick out vertically like a pencil in the speech of Sonneratia spp and Avicennia spp. fires; has seeds (propagules) that are viviparous or can germinate on the tree, especially on Rhizophora; has a lot of lenticels on the bark. Whereas the mangrove forest is a unique habitat and has special characteristics, including: the land is periodically flooded with sea water, either every day or only flooded at high tide; the place receives an adequate supply of fresh water from land; the area is protected from 
large waves and strong tidal currents; brackish water (salinity) brackish water (2-22 \%o) (LPP Mangrove, 2008).

The characteristics of mangrove ecosystems are influenced by soil conditions, salinity, inundation, tides, and oxygen content. The adaptation of mangrove plants to these habitats can be seen in the morphology and structure composition of mangrove plants ${ }^{7}$.

The total area of Sungai Berang protected forest reaches 4.625 hectares including 529 hectares of mangrove vegetation. From this area, the area surveyed is 1.500 hectares, which is located around the Muara Sungai Berang. From the 1.500 hectares area, the area that was considered suitable and had good prospects was chosen to be developed into a mangrove tourism area of 500 hectares. Based on survey results and orientation in the field of prospective areas in accordance with the carrying capacity of the area (potential and other biophysical conditions) as well as thesocio-economic and cultural conditions of the communities surrounding the mangrove forest area, the area chosen as a tourist forest area at this early stage is located at coordinates $107^{0} 34^{\prime} 45^{\prime \prime}-107^{0} 35^{\prime} 30^{\prime \prime}$ East longitude and $2^{0}$ $54^{\prime} 30^{\prime \prime}-2^{0} 56^{\prime} 00^{\prime \prime}$ South latitude. The selected area consists of a mangrove forest with an area of 140 hectares, and the remaining 360 hectares is a lowland forest vegetated forest with a total length of mangrove area is 11,588 meters.

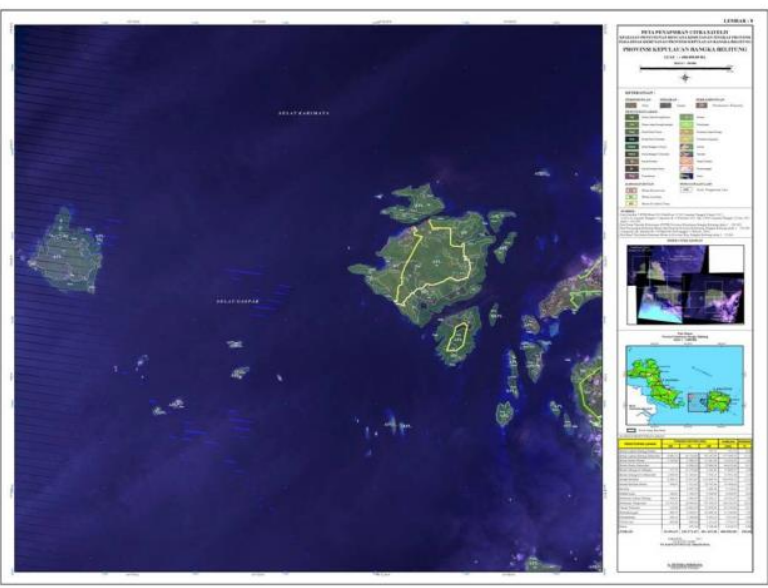

Fig 1. Location of mangrove tourism area on Nasik Strait Island. Source: The Provincial Government of Bangka Belitung

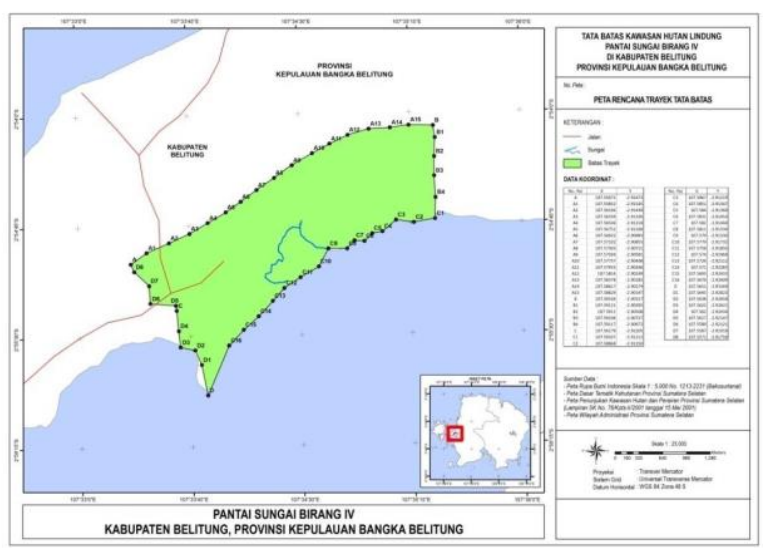

Fig 2. Map of boundaries of Sungai Berang Mangrove Tourism Area Source: The Provincial Government of Bangka Belitung 


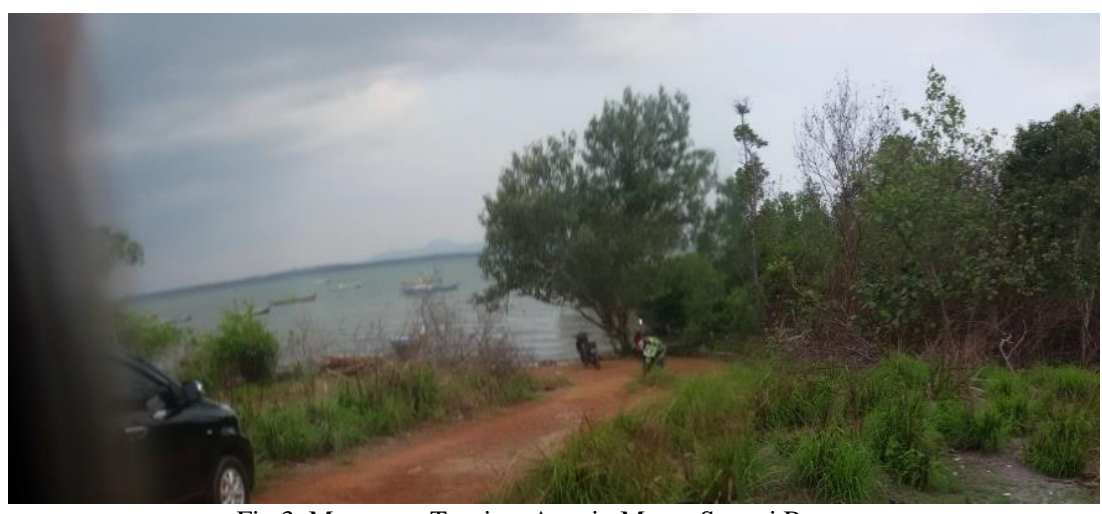

Fig 3. Mangrove Tourism Area in Muara Sungai Berang.

Source: Field Survey 2018

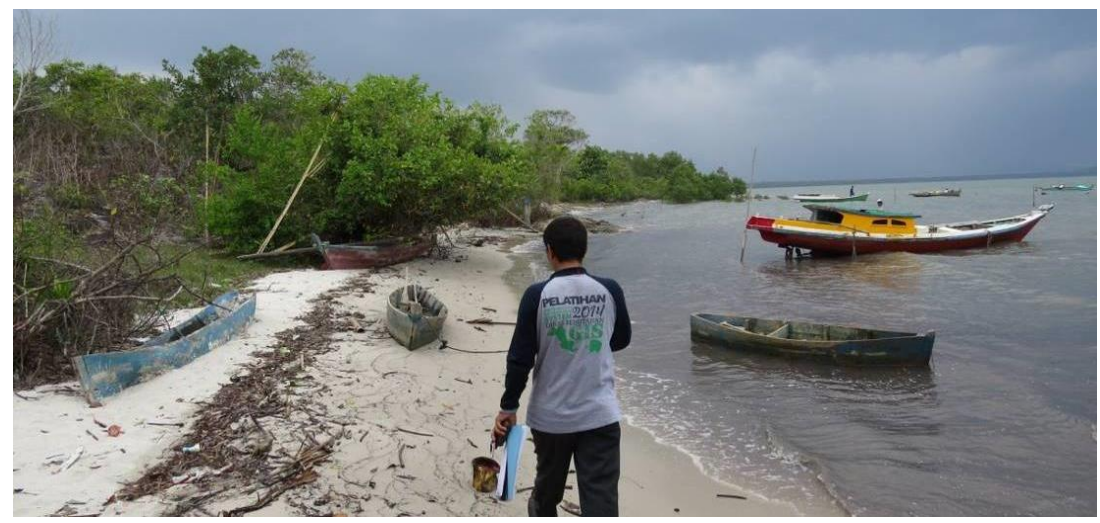

Fig 4. Mangrove Tourism Area in Muara Sungai Berang beach Source: Field Survey 2018

Table 1. Outside Boundary Routes of Mangrove Tourism Forest Areas in Protected Forest Areas Sungai Berang Source: Field Survey 2018

\begin{tabular}{|c|c|c|c|c|c|}
\hline \multirow[b]{2}{*}{ No. } & \multirow[b]{2}{*}{ Route } & \multirow[b]{2}{*}{ Long (m) } & \multicolumn{3}{|c|}{ Coordinate } \\
\hline & & & & & $\mathbf{Y}$ \\
\hline 1 & $\mathrm{~A}-\mathrm{A} 1$ & 250 & $\mathrm{~A}$ & 107.55672 & -2.91673 \\
\hline 2 & $\mathrm{~A} 1-\mathrm{A} 2$ & 250 & A1 & 107.55852 & -2.91545 \\
\hline 3 & $\mathrm{~A} 2-\mathrm{A} 3$ & 250 & A2 & 107.56106 & -2.91438 \\
\hline 4 & $\mathrm{~A} 3-\mathrm{A} 4$ & 250 & A3 & 107.56339 & -2.91336 \\
\hline 5 & A4 - A5 & 250 & A4 & 107.56546 & -2.91218 \\
\hline 6 & A5 - A6 & 250 & A5 & 107.56752 & -2.91100 \\
\hline 7 & A6 - A7 & 250 & A6 & 107.56922 & -2.90983 \\
\hline 8 & A7 - A8 & 250 & A7 & 107.57102 & -2.90865 \\
\hline 9 & A8 - A9 & 250 & A8 & 107.57303 & -2.90721 \\
\hline 10 & A9 - A10 & 250 & A9 & 107.57504 & -2.90581 \\
\hline 11 & $\mathrm{~A} 10-\mathrm{A} 11$ & 250 & $\mathrm{~A} 10$ & 107.57737 & -2.90448 \\
\hline 12 & A11 - A12 & 250 & A11 & 107.57933 & -2.90346 \\
\hline 13 & $\mathrm{~A} 12-\mathrm{A} 13$ & 250 & A12 & 107.58140 & -2.90249 \\
\hline 14 & A13 - A14 & 250 & A13 & 107.58378 & -2.90185 \\
\hline 15 & A14 - A15 & 250 & A14 & 107.58617 & -2.90174 \\
\hline 16 & A15 - B & & A15 & 107.58829 & -2.90147 \\
\hline 17 & B - B1 & 250 & B & 107.59104 & -2.90157 \\
\hline 18 & B1 - B2 & 250 & B1 & 107.59121 & -2.90295 \\
\hline 19 & B2 - B3 & 250 & B2 & 107.59110 & -2.90508 \\
\hline 20 & B3 - B4 & 250 & B3 & 107.59106 & -2.90727 \\
\hline 21 & B4 - C & 250 & B4 & 107.59117 & -2.90972 \\
\hline 22 & $\mathrm{C}-\mathrm{C} 1$ & 250 & $\mathrm{C}$ & 107.56179 & -2.92205 \\
\hline 23 & $\mathrm{C} 1-\mathrm{C} 2$ & 250 & $\mathrm{C} 1$ & 107.59107 & -2.91212 \\
\hline 24 & $\mathrm{C} 2-\mathrm{C} 3$ & 250 & $\mathrm{C} 2$ & 107.58868 & -2.91250 \\
\hline 25 & $\mathrm{C} 3-\mathrm{C} 4$ & 250 & C3 & 107.58667 & -2.91219 \\
\hline 26 & $\mathrm{C} 4-\mathrm{C} 5$ & 250 & $\mathrm{C} 4$ & 107.58513 & -2.91347 \\
\hline 27 & C5 - C6 & 250 & C5 & 107.58397 & -2.91368 \\
\hline 28 & C6 - C7 & 250 & C6 & 107.58307 & -2.91454 \\
\hline 29 & $\mathrm{C} 7-\mathrm{C} 8$ & 250 & C7 & 107.58195 & -2.91444 \\
\hline 30 & C8 - C9 & 250 & $\mathrm{C} 8$ & 107.58111 & -2.91534 \\
\hline 31 & C9- C10 & 250 & C9 & 107.57899 & -2.91530 \\
\hline 32 & $\mathrm{C} 10-\mathrm{C} 11$ & 250 & C10 & 107.57788 & -2.91732 \\
\hline
\end{tabular}




\begin{tabular}{|l|c|c|c|c|c|}
\hline 33 & C11 - C12 & 250 & C11 & 107.57581 & -2.91850 \\
\hline 34 & C12 - C13 & 250 & C12 & 107.57396 & -2.91968 \\
\hline 35 & C13 - C14 & 250 & C13 & 107.57264 & -2.92112 \\
\hline 36 & C14 - C15 & 250 & C14 & 107.57100 & -2.92283 \\
\hline 37 & C15 - C16 & 250 & C15 & 107.56930 & -2.92433 \\
\hline 38 & C16 - D & 250 & C16 & 107.56761 & -2.92609 \\
\hline 39 & D - D1 & 250 & D & 107.56513 & -2.93169 \\
\hline 40 & D1 - D2 & 250 & D1 & 107.56449 & -2.92823 \\
\hline 41 & D2 - D3 & 250 & D2 & 107.56379 & -2.92658 \\
\hline 42 & D3 - D4 & 250 & D3 & 107.56215 & -2.92621 \\
\hline 43 & D4 - D5 & 250 & D4 & 107.56198 & -2.92434 \\
\hline 44 & D5 - D6 & 250 & D5 & 107.56171 & -2.92147 \\
\hline 45 & D6 - D7 & 250 & D6 & 107.55885 & -2.92121 \\
\hline 46 & D7 - D8 & 250 & D7 & 107.55874 & -2.91918 \\
\hline 47 & D8 - A & 88 & D8 & 107.55709 & -2.91758 \\
\hline
\end{tabular}

\section{METHODOLOGY}

Data collection methods used include primary data which is a source of data obtained directly from the original source (not through an intermediary) in the form of an individual or group subject (person) opinion, observations of an object (physical), event or activity, and test results. Primary data were obtained from site location surveys and interviews. Secondary data itself is research data obtained indirectly through intermediary media generally in the form of evidence, historical records or reports that have been arranged in published and unpublished archives. The analysis method is the analysis of space composition, analysis of the achievement of accessibility, infrastructure analysis and management analysis. The concept approach is carried out through the Basic Strategy Approach, Operational Strategy Approach, Special Approach. The concept of architecture is a generalized idea which is the result of analysis that has been carried out the spatial concept, the concept of accessibility, the concept of recreational infrastructure and the concept of management.

\subsection{Basic Strategy Approach}

In the implementation of this work the basic strategy will be used as a soul in every implementation of the activity stages. The basic strategies include, (1) Collaboration with all stakeholders, especially when collecting secondary and primary data, (2) Optimization, both the process and the results can run optimally and can satisfy all parties, (3) Accountability, that all implementation activities are carried out done must be able to be accounted for in the future and measured, especially in the management of all data, (4) Innovation, as a translation of a relatively new idea, innovation is needed so that the formulation of the concept of technical guidance, provision of guidelines, training guidance and direction to provincial, city / district governments through structural services used will be well received by all parties

\subsection{Operational Strategy Approach}

To ensure that the performance of operational operations is maintained, so as to be able to achieve the goals and targets that have been set previously. The operational strategies referred to are, (1) Data collection (Data Collecting), both in the form of primary data and secondary data needed to analyze, (2) Reporting, to document all the results of activities carried out from commencement to completion of work, (3) Confirmation, confirmation by a visit or field survey to the study location and to several parties who will become users. This confirmation is held in the form of discussions at each stage of the report and seminars at the concept plan stage, (4) Continuous Coordination, which will involve many parties, especially at the stage of data collection, discussion and discussion.

\subsection{Special Approach}

The specific approach referred to in terms of carrying out work is the flow of thought that is described as an instrument in completing work. This special approach

\section{ANALYSIS DISCUSSION AND RESULTS}

The development of the Mangrove Ecosystem Tourism Master Plan Belitung District was obtained from a combination of figurative New Green Plans and natural green space conservation. The concept of Eco Nature Park is the most possible alternative, namely the regional spatial concept that pays attention to environmental ecology, green spatial design, open space layout, regional landscaping, reservoir edge landscape, naturally, figurative, beautiful and having a certain atmosphere. Mangrove tourism is a public space that can be demanded without space restrictions. In the planning effort, it is important to consider the characteristics of the land, namely the nature of the land and its activities. Mangrove tourism area has a distinctive character that is green land and reservoir water, which depends on space and time. In addition, the area is easily recognizable from its environment, which consists of nonphysical elements in the form of user activity and experience and physical elements in the form of a Green Belt environment. In an area the physical and non-physical elements are in a relationship. This linkage visually and sequentially can shape the visual environment 


\section{NATURAL PARK EKO PLANNING POLICY CONCEPTS}

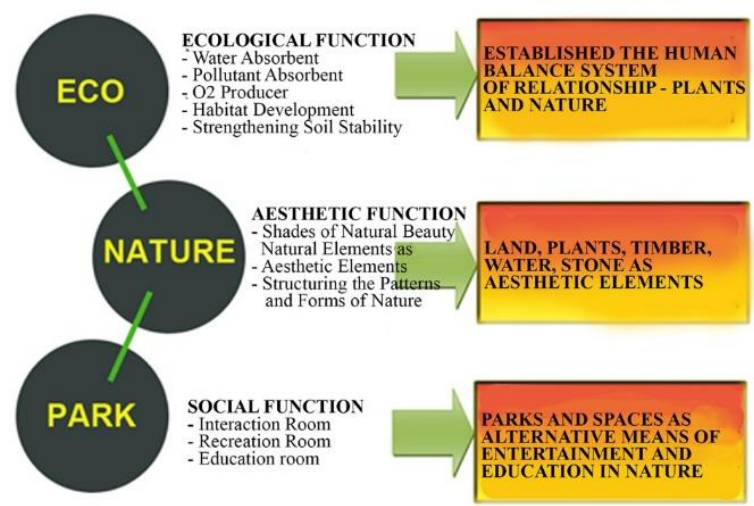

Fig 5. Chart of Eco Nature Park Concepts

\subsection{SPATIAL PLAN}

In accordance with the concept developed and the optimality of the utilization of its resources, the sites and spaces in the Sungai Berang Mangrove Tourism Forest area are divided based on the function of interest, namely: (1) Protection, the space allocated to maintain the preservation of the mangrove forest so that the protection function (such as a filter salinity to the mainland, preventing coastal abrasion) can run well, (2) Conservation, the space allocated for the conservation of mangrove forests. This space is more focused on the physical growth of mangroves to achieve the protection function of the area, (3) Tourism/Recreation, space allocated for recreational functions and activities of visitors both for passive and active recreational activities.

Based on the visiting area, space will be developed with the nature of the visit which is oriented towards, (1) Reception Space, which is the space that is entered at the initial stage of the visit. This space is more welcome to the mangrove tourism area. The character is natural-semi-natural and endeavored to contain elements of local architecture which are reflected in the design of the gate. In this area transit facilities will only be provided such as a parking area (limited), the manager's office, the main rangers post and the area information board that gives an overview of the Sungai Berang Mangrove Tourism area, (2) Utilization Space, which is the space after the receiving room. Actually this space is not part of the mangrove area, but it is proposed to be included in the planning area. The consideration is to place supporting facilities that are not possible to place in the transitional space or in the conservation space. This utilization space is more for supporting space, where there are additional activities such as community economic activities such as selling food, selling souvenirs, area information etc. which are facilitated by small stalls with local architecture and lightweight materials. It also introduced other activities such as camping areas, outbound areas, which are placed to give other colors to this region. This space is also allocated as an intensive area in its use, (3) Transition Space, is a preparation room for entering the ecological space. This space is dominated by an atmosphere of natural character and is allocated as a semi-intensive visiting area. In this space facilities are placed to enjoy the mangrove area, (4) Conservation Space, a space that describes the whole condition of this mangrove forest. Visits to this area are only passive, very limited and only to increase knowledge and knowledge of the Sungai Berang Mangrove Tourism Forest. This space can be reached by road (broadwalking), enjoyed through binocular viewing towers, or enjoyed through waterways (speedboats and rowboats or floating bridges). The interrelations of the various spaces developed based on the function and area of the visit in the Berang Sungai Mangrove Tourism Forest can be seen in Table 2

Table 2. Linkages between Spatial Planning and Management in Sungai Berang Mangrove Tourism Forest Area

\begin{tabular}{|c|c|c|c|}
\hline \multirow{2}{*}{ FUNCTION } & \multicolumn{3}{|c|}{ VISIT AREA } \\
\cline { 2 - 4 } & Utilization & Transitions & Ecological \\
\hline Protection & None & None & Must \\
\hline Conservation & None & Facultative & Must \\
\hline Recreation & Intensive & Facultative & Facultative \\
\hline
\end{tabular}

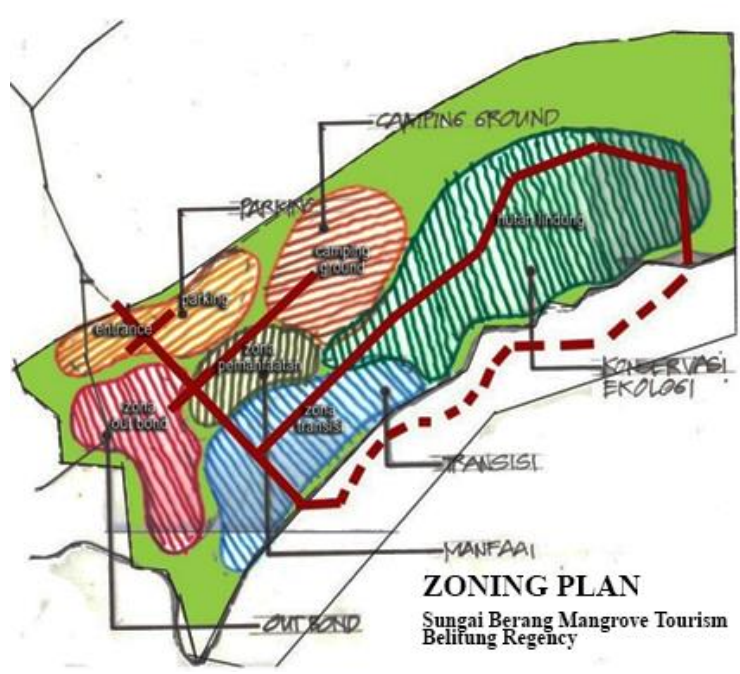

Fig 6. Sungai Berang Mangrove Tourism Zoning, Belitung Regency

\subsection{CIRCULATION ACCESSIBILITY}

The site has relatively high accessibility from land, river (allows) and sea. This easy achievement has positive values (can reach sites from all directions) and negative (damage or disruption to potential sites from all directions). Therefore, special doors need to be planned that optimizes the ease of use, can be managed safely, but also can reduce habitat damage.

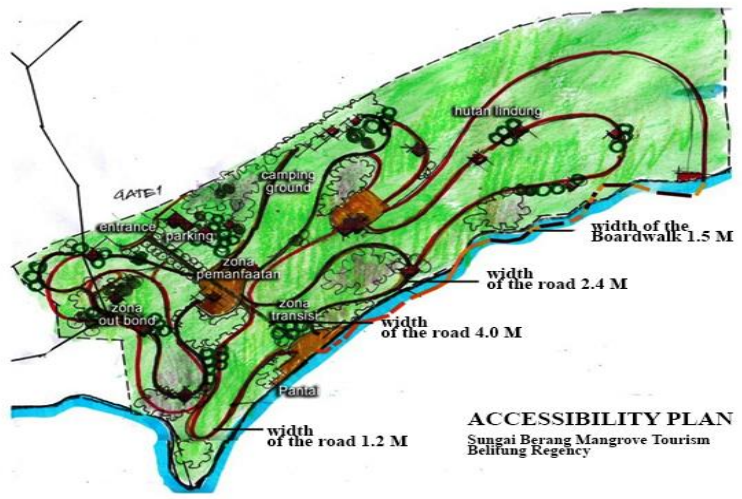

Fig 7. Accessibility of Sungai Berang Mangrove Tourism 
The circulation network system in Sungai Berang Mangrove Tourism Forest $\mathrm{t}$ is planned to support the development goals and optimal utilization of existing resources and which can be developed from the site. Therefore, the circulation path in the Sungai Berang Mangrove Tourism Forest is endeavored to be able to compile various natural events that form mangrove conditions or that can be enjoyed in this area (ecosystems, biota, coastal areas, etc.).

\subsection{SUPPORTING FACILITIES AND LAYOUTS}

To be able to develop and utilize the site in accordance with the goals and potential of its natural resources, supporting facilities are proposed. Various supporting facilities are planned to spread in every area starting from the recipient and service, utilization, transition and conservation with natural patterns and formations. Table 2. shows the type and distribution of space for placement from this support structure.

Table 2. Types and Spaces of Facilities Supporting Sungai Berang Mangrove Tourism Forest

\begin{tabular}{|c|c|c|c|c|c|c|}
\hline \multirow[b]{2}{*}{ No. } & \multirow[b]{2}{*}{ FUNCTION } & \multirow{2}{*}{ Facilities and Infrastructure } & \multicolumn{4}{|c|}{ LAYOUT IN SITE } \\
\hline & & & Receiver & Utilization & Transition & Ecology \\
\hline \multirow[t]{13}{*}{1.} & Total Area Management & & & & & \\
\hline & $\begin{array}{l}\text { a. Administration } \\
\text { Management }\end{array}$ & 1. Main Head Office & o & & & \\
\hline & & 2. Vehicle Parking & o & & & \\
\hline & & 3. Guard House & o & $\mathrm{O}$ & o & o \\
\hline & & 4. Entrance Gate & $\mathrm{O}$ & & & \\
\hline & b. Physics Management & 1. Main Dock System & & & & o \\
\hline & & 2. The utility & o & o & o & \\
\hline & & 3. Fresh Water & o & & & \\
\hline & & 4. Counseling Information Center & o & o & o & \\
\hline & & 5. Worship place & & o & & \\
\hline & & 6. Information Signs & o & o & o & o \\
\hline & & 7. Boundary Sign & o & o & $\mathrm{O}$ & $\mathrm{O}$ \\
\hline & & 8. Trash Can (Local And Collector) & o & o & o & \\
\hline \multirow[t]{18}{*}{2.} & Special Managemnt & & & & & \\
\hline & a. Protection & 1. Guard House & & & o & o \\
\hline & & 2. Information Signs & & & o & o \\
\hline & & 3. Boardwalk & & & o & o \\
\hline & & 4. Boundary Sign & $\mathrm{O}$ & $\mathrm{o}$ & $\mathrm{O}$ & $\mathrm{O}$ \\
\hline & b. Concervation & 1. Guard House & & & o & $\mathrm{O}$ \\
\hline & & 2. Information Signs & & & o & o \\
\hline & & 3. Boardwalk & & & o & o \\
\hline & & 4. Boundary Sign & & & o & $\mathrm{o}$ \\
\hline & & 5. Lookout Tower & & & o & o \\
\hline & & 6. Main Dock System & & & o & o \\
\hline & & 7. Trash Can (Local And Collector) & & & o & o \\
\hline & c. Recreation & 1. Counseling Information Center & & o & o & o \\
\hline & & 2. Information Signs & o & o & o & o \\
\hline & & 3. Boardwalk & & o & o & o \\
\hline & & 4. Boundary Sign & o & o & $\mathrm{O}$ & $\mathrm{O}$ \\
\hline & & 5. Lookout Tower & & & o & o \\
\hline & & 6. Lookout Tower & o & o & o & $\mathrm{O}$ \\
\hline
\end{tabular}




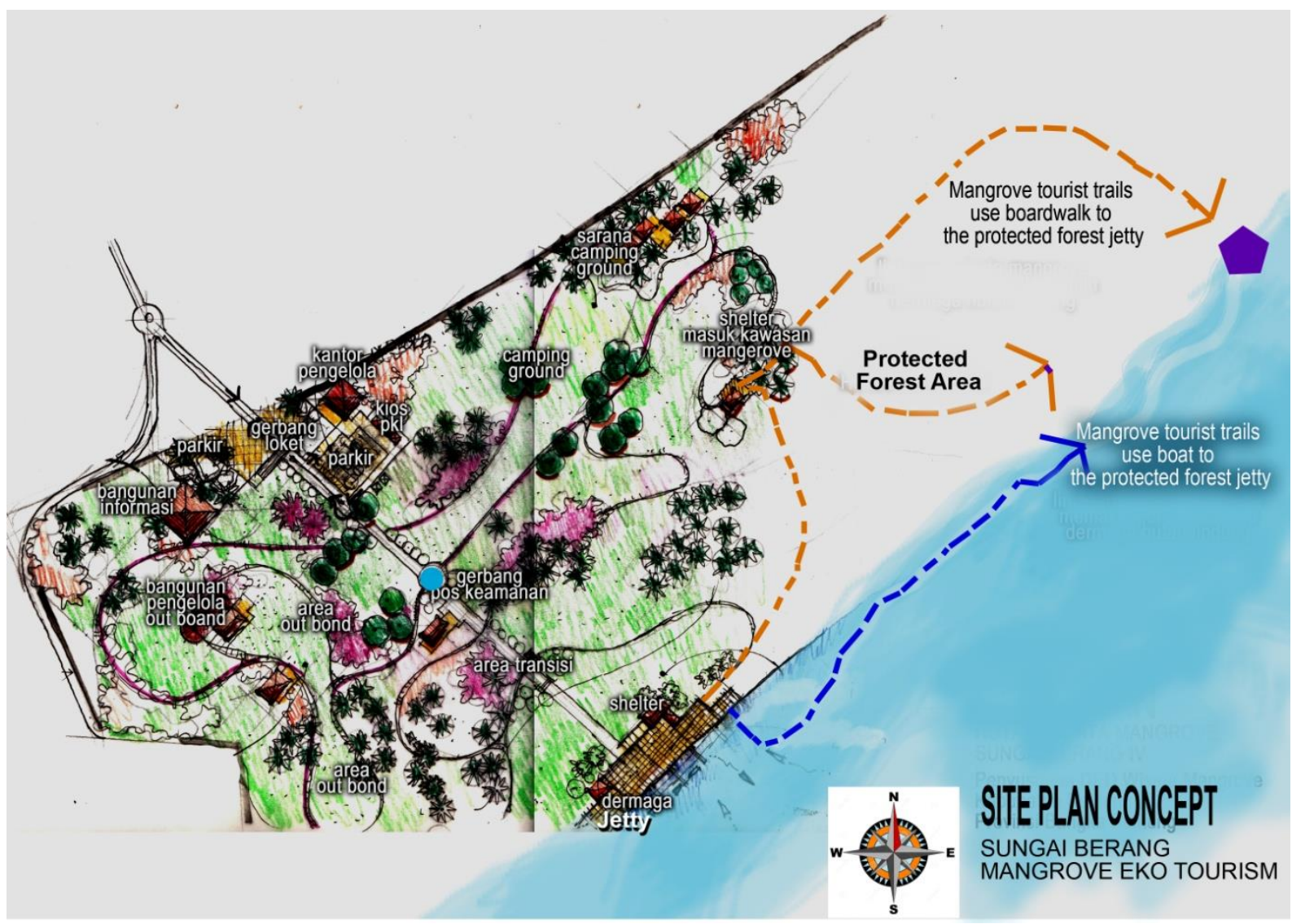

Fig 8. Sungai Berang Mangrove Tourism Forest Site Plan

\section{CONCEPT OF MANAGEMENT PLAN}

Management of the area opened as a limited natural tourism area is very necessary so that this area can continue to function in a sustainable manner, both its function of protection of the area, its economic function as a limited natural tourism area and people's livelihoods and social functions for the surrounding community. Community participatory approach can be applied in order to maintain and maintain the sustainability of the existence of the region along with the functions that are in it. In this participatory approach, the surrounding community is involved directly and actively, especially in the main activities of tourism and its derivatives. After this tourism area is opened, the community can be involved from the economic sector, for example boat rental, local cuisine, tour guides, making local souvenirs and so on. This will provide a strong motivation for the community to protect and maintain the Berang Sungai Mangrove Tourism Forest Area, because their future will certainly be affected if the area is damaged and not maintained.

\section{CONCLUSION}

The mangrove forest area with the natural formation of the Sungai Berang Protection Forest as a whole in order to be immediately rehabilitated and its optimal use must be endeavored considering the importance and uniqueness obtained, both the formation of mangrove forests and as a very important ecological multi-function space.

This area is divided into 3 (three) parts of each spatial shape based on its function, designating the visiting area, and mangrove management. Circulation network connecting the facility space in Mangrove Tourism Forest is planned not only for its utilization but also its management. The architectural order produced is then optimized with the condition of mangrove resources, constraints of pressure from outside the site, as well as the principle of controlled utilization so as to produce a site development plan for the mangrove forest.

In the framework of sustainable management of mangrove tourism forests, 4 (four) forms of management are proposed, namely those related to Vegetation and Wildlife Management, Waste and Waste Management, Visitor Management, and Management of Community Participation.

\section{REFERENCES}

[1] Rutana, F, F. 2011. Studi Kesesuaian Ekosistem, Manggrove sebagai Objek Ekowisata di Pulau Kapota Taman Nasional Wakatobi Sulawesi Tenggara. Universitas Hasanuddin, Makasar. 
[2] Damamik, J. dan H.F. Weber. 2006.Perencanaan Ekowisata: dari Teori ke Aplikasi Buku. Pusat Studi Pariwisata UGM dan ANDI Yogyakarta. Yogyakarta. $142 \mathrm{p}$.

[3] Hakim Rustam. 2012. Komponen Perancangan Arsitektur Lansekap: Prinsip-unsur dan Aplikasi Desain. Penerbit PT Bumi Aksara. Jakarta. $384 \mathrm{p}$

[4] Duke, N.C. 1992. Mangrove floristics and biogeography. In: Robertson, A.I. and Alongi, D.M. (eds.), Tropical Mangrove Ecosystems. pp. 63-100. American Geophysical Union, Washington, D.C.

[5] Kusmana, C. 2005. Rencana Rehabilitasi Hutan Mangrove dan Hutan Pantai Pasca Tsunami di NAD dan Nias. Makalah dalam Lokakarya Hutan Mangrove Pasca Tsunami, April 2005. Medan

[6] Sumaharni. 1994. Rehabilitasi Hutan Mangrove Terdegradasi Dengan Sistem Perhutan Nasional. Prosiding Ekosistem Mangrove. Halaman 110-116

[7] Rismunandar, 2000. Laju Dekomposisi Serasah Daun Avicennia marina pada Berbagai Tingkat Salinitas (Studi Kasus di Kawasan Hutan Mangrove Blanakan, RPH Tegal Tangkil, BKPH CiasemPamanukan, KPH Purwakarta, Perum Perhutani Unit III Jawa Barat. 